\title{
Assessment of probiotic application of lactic acid bacteria (LAB) isolated from different food items
}

\author{
Mahbubul Hasan Siddiqee, ${ }^{1 \ddagger}$ Hashem Sarker $^{2}$ and Khandaker Mahzebin Shurovi ${ }^{2}$ \\ ${ }^{1}$ Microbiology Program, Department of Mathematics and Natural Sciences, BRAC University, Dhaka-1212, Bangladesh; \\ ${ }^{2}$ Department of Microbiology, Stamford University Bangladesh, Dhaka-1217, Bangladesh
}

Received 10 July 2012/Accepted 29 September 2012

\begin{abstract}
Lactic acid bacteria (LAB) are regarded as effective probiotic organisms and used with a view of augmenting the safety of the food. In the present study, five food items (meat, fish, apple, milk and carrot) were selected having high nutritive and economic value, assumptive of harboring lactic acid bacteria. A total of 29 LABs were isolated from 5 different samples after 2 batches of fermentation. All of the isolates were then tested against 4 most frequently encountered pathogens, Staphylococcus aureus, Escherichia coli, Salmonella typhimurium, and Vibrio cholerae. Among all these isolates, those from meat and fish samples showed positive average inhibitory coefficient (AIC) against two target pathogens, while those from milk and carrot showed positive AIC against three pathogens each, and isolates from apple revealed positive AIC against all four pathogens used. More than $50 \%$ of the isolates were found to inhibit or mask the pathogens when allowed to grow along with the individual pathogen on the each tested food item. Out of 29 isolates, 17 were found to successfully inhibit Escherichia coli, 11 worked against $S$. aureus, 11 against $S$. typhimurium, and 13 showed significant effect against $V$. cholerae. Among these isolates ML4, ML8, AP5 and CR3 most notably showed the potential to inhibit or mask at least three of the target pathogenic strains.
\end{abstract}

Key words: Lactic acid bacteria; probiotics; competitive inhibition

A large proportion of diseases originate from food rendered as unsafe due to bacterial growth or toxin production, hence everyone is at risk from food-borne illness (1). Thus bacteria could pose a great threat to food safety and security. On the other hand, bacteria have been used in ensuring food safety and food preservation for over 6,000 years $(2,3)$. It is an inexpensive and manageable tool, which imparts some extrinsic defenses to the food while leaving the intrinsic defense factors of the food unchanged (4). All these factors have cumulative or individual effects antagonistic to pathogenic or toxigenic microorganisms that render the food safer $(5,6)$. On top of that, nutritional value of food fermented with bacteria when compared to non fermented one is higher regarding protein, vitamin and mineral contents (7).

Fermentation processes enhance food safety by reducing toxic compounds such as aflatoxins and cyanogens, and producing antimicrobial factors such lactic acid, bacteriocins, carbon dioxide, hydrogen peroxide and ethanol which facilitate inhibition or elimination of food-borne pathogens (8-10). Therapeutic properties of fermented foods have also been reported (11). In addition to its nutritive, safety and preservative effects, fermentation process imparts

${ }^{\ddagger}$ Corresponding Author: Mailing address. Mahbubul Hasan Siddiqee, Microbiology Program, Department of MNS, BRAC University, 66 Mohakhali, Dhaka, Bangladesh; E-mail: msiddiqee@bracu.ac.bd. a diversity of flavors, textures and aromas (12).

The most common probiotic candidate within the human digestive tract is the Lactobacillus spp. $(13,14)$. Some strains of Lactobacillus acidophilus have natural antibiotic producing and cancer fighting properties (15). These strains are particularly beneficial against infectious bacteria such as Streptococcus, Staphylococcus, Salmonella, Clostridium botulinum, and E. coli (16-19). Some strains of $L$. acidophilus have even shown impressive effects against viral infections including polio, HIV, and herpes $(20,21)$, and can also produce hydrogen peroxide which has the potential to kill undesirable Candida yeast and prevent its overgrowth (19).

Lactic acid bacteria are known to release various enzymes and vitamins into the intestinal lumen (22). These exert synergistic effects on digestion, alleviating symptoms of intestinal malabsorption (13). Bacterial enzymatic hydrolysis may enhance the bioavailability of protein and fat (23) and increase the production of free amino acids, short chain fatty acids (SCFA), lactic acid, propionic acid and butyric acid (24). When absorbed, these SCFAs contribute to the available energy pool of the host $(25,26)$ and may protect against pathological changes in the colonic mucosa $(27,28)$.

The present study was undertaken to isolate lactic acid bacteria (LAB) from some foods known to support LAB growth with a view of using the isolates in the long run to ferment those foods, and determination of their interactions with some food-borne pathogenic bacteria 
frequently encountered in Bangladesh (29). As there is no published report on assessing the efficacy of LABs against pathogens in Bangladesh, this study was carried out to shed some light on that.

\section{MATERIALS AND METHODS}

Samples chosen for this study were selected on the basis of higher possibility of harboring naturally occurring LAB (30) as well as having higher promise in terms of economic and nutritional value. Samples included meat (beef), cowmilk, fish (Pangasius bocourti), apple and carrot.

Sample processing. Two batches of samples were collected from Karwan Bazar and Moghbazar markets in Dhaka city. About 100g of sample for each item was collected aseptically using sterile container. Approximately $20 \mathrm{~g}$ of each sample (except milk) were mixed with $80 \mathrm{ml}$ of sterile water and then homogenized with stomacher for 5-10 minutes and then 10 fold dilution was performed once. $\mathrm{pH}$ was recorded for each homogenized sample before adjusting it to 5.5 to give selective advantage to the LAB.

Isolation of LABs. Processed samples were kept at room temperature inside paper boxes for 3 days for natural fermentation to occur. Then, dilution up to $10^{-6}$ was performed for each fermented sample. $0.1 \mathrm{ml}$ from each sample was spread on Rogosa SL Agar and incubated at $37{ }^{\circ} \mathrm{C}$ for 48 hours under limited oxygen concentration by sealing the agar plates with parafilm.

Pathogenic microrganisms. Four clinical isolates including Staphylococcus aureus, E. coli, S. typhimurium, and V. cholerae were collected from Microbiology Laboratory of Stamford University Bangladesh. These pathogens were selected due to their involvement in food-borne gastrointestinal illnesses.

Competitive inhibition assay (CIA). Four sets of test tubes (each for a target pathogen) were filled with $5 \mathrm{ml}$ of sterile homogenized food sample. In each set, one test tube was assigned for each bacterium isolated from the test samples. In addition, 5 test tubes were taken as negative control. Medium used for each of the isolates was the original food type from which the LABs were isolated, i.e. the isolates from meat samples were tested for interaction with the target pathogens in autoclaved homogenized meat, milk-isolates were tested against target pathogens in milk, and so on for the others. All the test tubes (except the negative controls) were inoculated with $0.1 \mathrm{ml}$ of each of the test organisms suspended in normal saline and kept for fermentation at $37{ }^{\circ} \mathrm{C}$. After 48 hours, 4 sets were inoculated with 4 target organisms respectively and were further incubated for 24 hours. 100-fold dilution was performed for each of the 4 sets of samples. Mannitol salt agar, MacConkey agar, Salmonella-Shigella agar, and thiosulfate-citrate-bile salt-sucrose agar were used for enumeration of S. aureus, E. coli, S. typhimurium, and V. cholerae, consecutively. Average Inhibition Coefficient (AIC) for each group of LAB isolated from a particular type of food against each of the four target pathogens was determined by using the following formula-

Average Inhibition Coefficient $($ AIC $)=[\{$ Total count in negative control Average count for each group of isolates \} / Total count in negative control].

\section{RESULTS}

Physical parameters. After initial processing, the $\mathrm{pH}$ of all the samples were measured and were found to range from 5.4 for apple to 7.1 for fish samples. The $\mathrm{pH}$ for all the samples was then adjusted to 5.5 and then, after fermentation, the $\mathrm{pH}$ was again measured for all the samples and found to be in range from 2.0 for carrot sample to 7.2 for meat sample (Fig. 1).

Frequency of LAB. After two batches of fermentation, a total of 29 bacteria were isolated. Among these 29 isolates, 3 (MT1-3) were found from meat samples, one (FS1) from fish samples, 9 (CR1-9) from carrot samples, 9 (ML1-9) from milk samples, and 7 (AP1-7) isolates were found from apple samples. All the isolates were presumptively confirmed to be LAB by Gram staining and subsequent observation under microscope for their characteristic morphology.

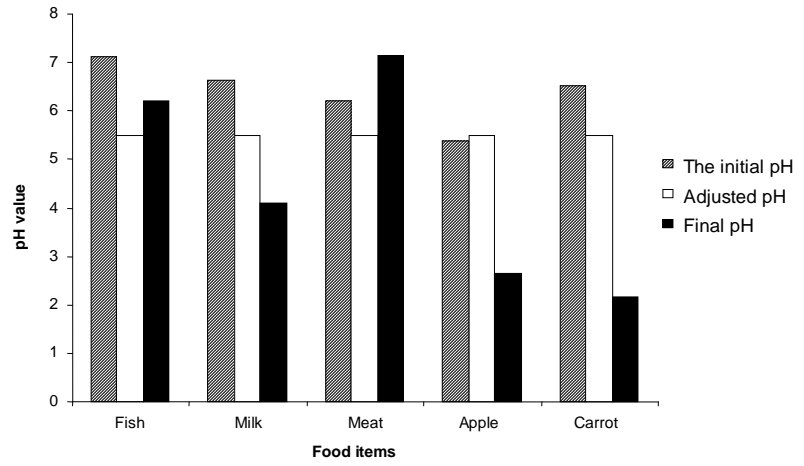

FIG. 1. Trend of $\mathrm{pH}$ change before and after fermentation. The bar chart indicates $\mathrm{pH}$ drops for milk, apple, and carrot samples while increases in case of fish and meat samples after fermentation.

Determination of AIC. After competitive inhibition assay (CIA), 3 meat isolates (MT1, MT2 and MT3) showed varied results (Table 1). MT1 showed positive result against $E$. coli, MT2 against all stains but $S$. aureus, and MT3 were positive against 2 of the target strains, namely E. coli and S. typhimurium. Overall, E. coli was inhibited with an average inhibition coefficient (AIC) of 0.95 while $S$. typhimurium was also moderately inhibited (Fig. 2a).

TABLE 1 . Count $\left(10^{3} \mathrm{cfu} / \mathrm{ml}\right)$ of target pathogens after competition with meat isolates

\begin{tabular}{ccccc}
\hline Isolate & $\begin{array}{c}\text { Staphylocuccus } \\
\text { aureus } \\
(\mathrm{cfu} / \mathrm{ml})\end{array}$ & $\begin{array}{c}\text { Escherichia } \\
\text { coli } \\
(\mathrm{cfu} / \mathrm{ml})\end{array}$ & $\begin{array}{c}\text { Salmonella } \\
\text { typhimurium } \\
(\mathrm{cfu} / \mathrm{ml})\end{array}$ & $\begin{array}{c}\text { Vibrio } \\
\text { cholerae } \\
(\mathrm{cfu} / \mathrm{ml})\end{array}$ \\
\hline MT1 & 280 & 5 & 172 & 70 \\
MT2 & 415 & 10 & 121 & 10 \\
MT3 & 370 & 4 & 2 & 125 \\
N.C. & 270 & 130 & 165 & 60 \\
\hline N.C. - Negative Control & & &
\end{tabular}

TABLE 2. Number $\left(10^{3} \mathrm{cfu} / \mathrm{ml}\right)$ of target pathogens after competition with fish isolates

\begin{tabular}{ccccc}
\hline Isolate & $\begin{array}{c}\text { Staphylocuccus } \\
\text { aureus } \\
(\mathrm{cfu} / \mathrm{ml})\end{array}$ & $\begin{array}{c}\text { Escherichia } \\
\text { coli } \\
(\mathrm{cfu} / \mathrm{ml})\end{array}$ & $\begin{array}{c}\text { Salmonella } \\
\text { typhimurium } \\
(\mathrm{cfu} / \mathrm{ml})\end{array}$ & $\begin{array}{c}\text { Vibrio } \\
\text { cholerae } \\
(\mathrm{cfu} / \mathrm{ml})\end{array}$ \\
\hline FS1 & 355 & 8 & 14 & 270 \\
N.C. & 159 & 225 & 46 & 170 \\
\hline
\end{tabular}

N.C. - Negative Control

The fish isolate showed positive result against $S$. typhimurium and $E$. coli, but was ineffective against $S$. aureus and $V$. cholerae ( Table 2). AIC for fish isolates was found to be 0.96 and thus very promising against $E$. coli, and fairly promising against $S$. typhimurium, while no such effect was observed against $S$. aureus or $V$. cholerae (Fig. 2b).

Milk isolates showed mixed result in CIA. Among 9 
isolates, S. aureus was inhibited by ML1, ML3, ML4, ML6, and ML8. E. coli was inhibited by ML1, ML4, ML5, ML7, and ML9. S. typhimurium was inhibited by ML1, ML 4, and ML8. V. cholerae was inhibited by ML1, ML 4, and ML8. ML4, ML5, and ML8. Among these isolates ML4 was found to have inhibited all four target strains (Table 3). Milk isolates showed fairly promising AIC against $S$. aureus (0.14) and E. coli $(0.36)$ but ineffective against $S$. typhimurium and $V$. cholerae (Fig. 2c).

Table 4 shows that $S$. aureus was inhibited by 4

A Effect of meat-isolates on target organisms

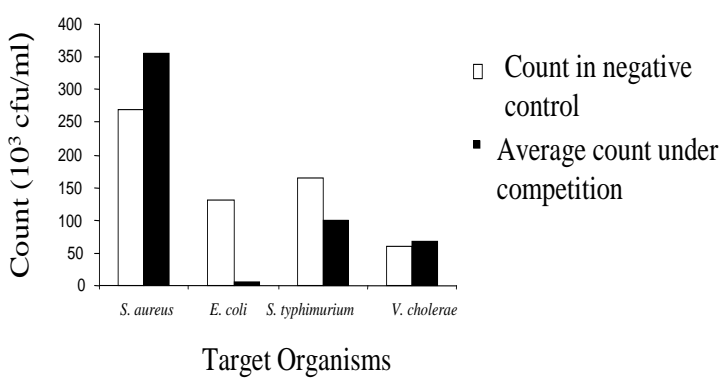

C

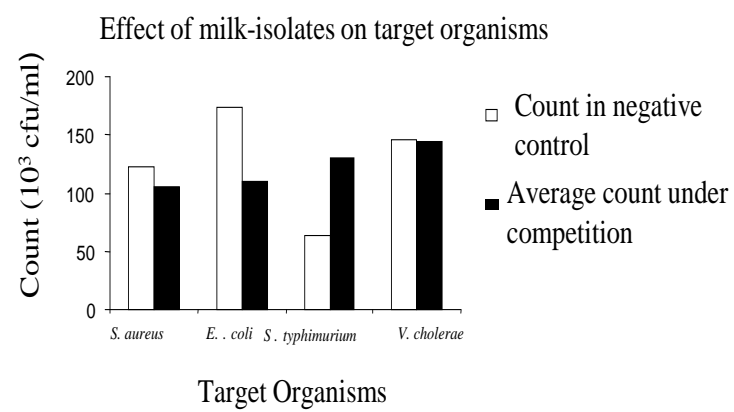

(AP2, AP4, AP5, AP7), E. coli was inhibited by 3 (AP1, AP4, AP6), S. typhimurium was inhibited by 2 (AP 2, AP5) and V. cholerae was inhibited by 3 (AP3, AP5, AP7) of the apple isolates. Overall, the apple isolates showed positive effect against all four target strains with AIC 0.33 against $S$. aureus, 0.23 against E. coli, 0.10 against $S$. typhimurium, and 0.26 against $V$. cholerae (Fig. 2d).

Table 5 shows that $S$. aureus was inhibited by 3 (CR1, CR2, CR7), E. coli was inhibited by 4 (CR3, CR5, CR8, CR9), S. typhimurium was inhibited by 3 (CR3, CR6,

B Effect of fish-isolates on target organisms
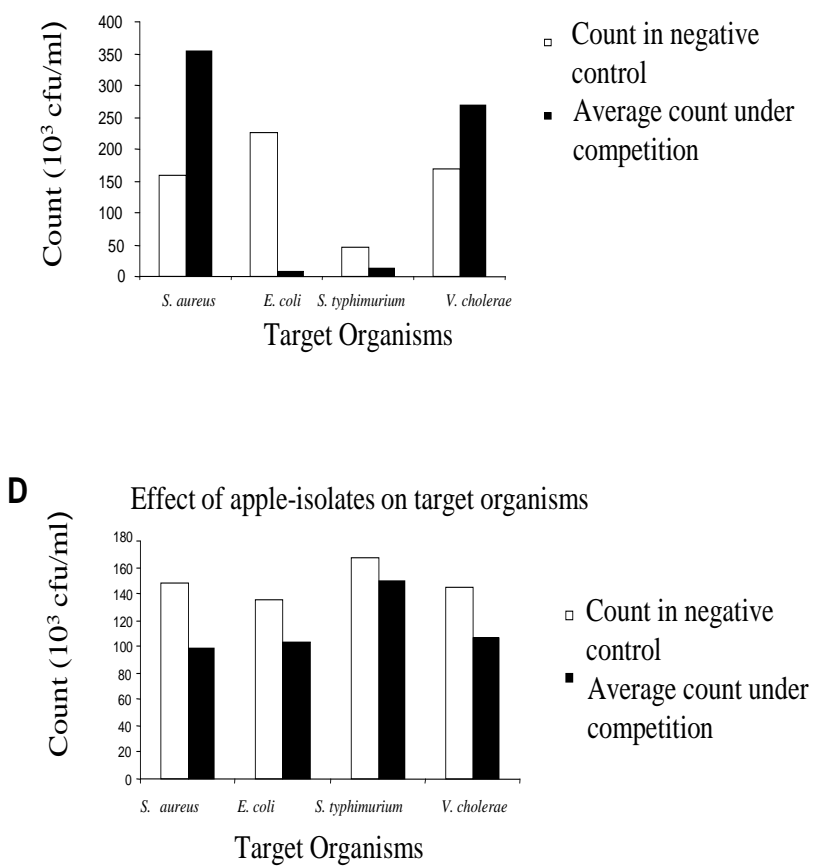

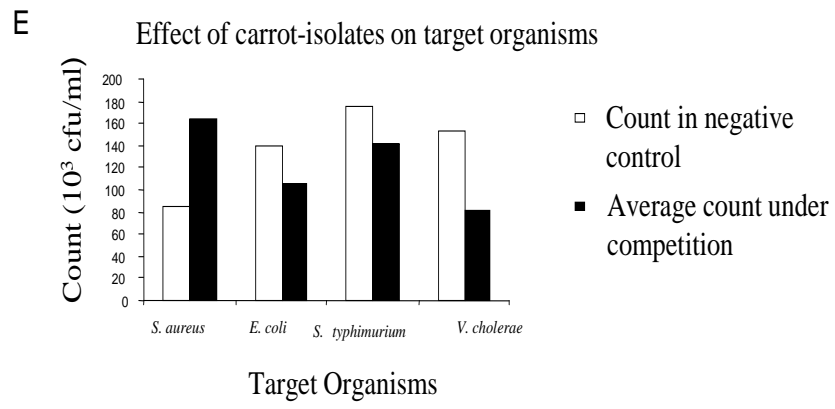

FIG. 2. Competative inhibition of the target pathogens by the LAB isolates. (A) isolates from meat and (B) fish showed average positive result against E. coli and S. typhimurium. Milk isolates (C) on an average were fairly inhibitive against E. coli only. Apple isolates (D) were moderatelyinhibitive against all four target pathogens and carrot isolates (E) on average were inhibitory against all but $S$. aureus. 
TABLE 3. Count $\left(10^{3} \mathrm{cfu} / / \mathrm{ml}\right)$ of target pathogens after competition with milk isolates

\begin{tabular}{ccccc}
\hline Isolate & $\begin{array}{c}\text { Staphylocuccus } \\
\text { aureus } \\
\text { (cfu/ml) }\end{array}$ & $\begin{array}{c}\text { Escherichia } \\
\text { coli } \\
\text { (cfu/ml) }\end{array}$ & $\begin{array}{c}\text { Salmonella } \\
\text { typhimurium } \\
\text { (cfu/ml) }\end{array}$ & $\begin{array}{c}\text { Vibrio } \\
\text { cholerae } \\
\text { (cfu/ml) }\end{array}$ \\
\hline ML1 & 5 & 28 & 71 & 183 \\
ML2 & 126 & 175 & 121 & 175 \\
ML3 & 4 & 227 & 141 & 271 \\
ML4 & 9 & 3 & 7 & 3 \\
ML5 & 274 & 14 & 174 & 1 \\
ML6 & 9 & 183 & 186 & 182 \\
ML7 & 172 & 4 & 227 & 155 \\
ML8 & 18 & 176 & 73 & 15 \\
ML9 & 204 & 14 & 115 & 173 \\
N.C. & 122 & 173 & 63 & 145 \\
\hline N.C. - Negative Control & & &
\end{tabular}

TABLE 4. Number $\left(10^{3} \mathrm{cfu} / \mathrm{ml}\right)$ of target pathogens after competition with apple isolates

\begin{tabular}{ccccc}
\hline Isolate & $\begin{array}{c}\text { Staphylocuccus } \\
\text { aureus } \\
\text { (cfu/ml) }\end{array}$ & $\begin{array}{c}\text { Escherichia } \\
\text { coli } \\
\text { (cfu/ml) }\end{array}$ & $\begin{array}{c}\text { Salmonella } \\
\text { typhimurium } \\
\text { (cfu/ml) }\end{array}$ & $\begin{array}{c}\text { Vibrio } \\
\text { cholerae } \\
\text { (cfu/ml) }\end{array}$ \\
\hline AP1 & 252 & 7 & 184 & 192 \\
AP2 & 10 & 149 & 5 & 170 \\
AP3 & 160 & 155 & 270 & 3 \\
AP4 & 4 & 4 & 216 & 162 \\
AP5 & 109 & 166 & 3 & 19 \\
AP6 & 153 & 5 & 195 & 184 \\
AP7 & 5 & 234 & 177 & 20 \\
N.C. & 148 & 135 & 167 & 145 \\
\hline N.C. - Negative Control & & &
\end{tabular}

CR8), and V. cholerae was found to be inhibited by 5 (CR2, CR3, CR5, CR7, CR9) of the carrot isolates. On an average, carrot isolates did not have any inhibitory role on $S$. aureus, moderately effective against $E$. coli and $S$. typhimurium, and fairly effective against $V$. cholerae with an AIC of 0.47 (Fig. 2e).

\section{DISCUSSION}

During the screening of LAB strains, it was very important to ensure ease and credibility. Various methods for this purpose were already reported by many researchers. Among those, spot-on-lawn assay, microtiter plate assay (31), agar well diffusion assay (32), multi-well plate assay (33), etc. were most notable. All of these techniques have few limitations. Moreover, as the goal of our experiment was to assess
TABLE 5. Number $\left(10^{3} \mathrm{cfu} / \mathrm{ml}\right)$ of target pathogens after competition with carrot isolates

\begin{tabular}{ccccc}
\hline Isolate & $\begin{array}{c}\text { Staphylocucc } \\
\text { us aureus } \\
\text { (cfu/ml) }\end{array}$ & $\begin{array}{c}\text { Escherichia } \\
\text { coli } \\
\text { (cfu/ml) }\end{array}$ & $\begin{array}{c}\text { Salmonella } \\
\text { typhimurium } \\
\text { (cfu/ml) }\end{array}$ & $\begin{array}{c}\text { Vibrio } \\
\text { cholerae } \\
\text { (cfu/ml) }\end{array}$ \\
\hline CR1 & 2 & 197 & 110 & 191 \\
CR2 & 9 & 174 & 192 & 1 \\
CR3 & 350 & 4 & 0 & 20 \\
CR4 & 360 & 182 & 223 & 142 \\
CR5 & 220 & 9 & 221 & 11 \\
CR6 & 174 & 158 & 5 & 179 \\
CR7 & 5 & 150 & 238 & 2 \\
CR8 & 154 & 30 & 9 & 172 \\
CR9 & 203 & 55 & 276 & 5 \\
N.C. & 85 & 140 & 175 & 152 \\
\hline N.C. - Negative Control & & &
\end{tabular}

the inhibitory effect of fermented foods, the experiment was designed accordingly. Competitive inhibition assay (CIA) was designed, keeping in mind the ultimate goal of fermentation. It was anticipated that the process of assessing the capacity of LABs to enhance microbiological safety of food by inhibiting pathogenic strains in food could effectively be carried out though leaving them to compete in similar environments. The intrinsic capacity of foods fermented with LABs to ward off pathogenic contaminants was put to test. In the end, the method was proven effective as a screening technique for identifying the promising strains as far as food borne bacterial illness is concerned. It ended up with unveiling 11 isolates to be effective against $S$. aureus, 17 against $E$. coli, 11 against $S$. typhimurium and 13 against $V$. cholerae.

In our study, average inhibition coefficient (AIC) was calculated for each food type against each of the target strains. It can be used as a gross parameter of the candidate LABs from each sample type. Isolates from apple origin showed most uniform index of AIC ranging from 0.10 to 0.33 which were found to be positive against all four target strains. Isolates from meat and fish could effectively suppress two of the target strains each; particularly, both groups were highly efficient against $E$. coli with AIC of 0.95 in fermented meat and 0.96 in fermented fish. Milk and carrot isolates revealed fairly positive AIC indicating the positive result.

One very important consideration is that the changes caused by fermentation can sometimes be disadvantageous. However, fermentation provides beneficial results if controlled carefully. It can therefore be a highly appropriate technique for use in developing countries and remote areas where access to sophisticated 
equipments is limited. If we can tackle the associated problems, lactic acid producing bacteria will not only serve as probiotic agents, but the microbiological food safety can also be ensured with considerable health and economic impact.

\section{REFERENCES}

1. Jean, C. B. and T. Roberts. 2009. The Economics of Enteric Infections: Human Foodborne Disease Costs. Gastroenterology 136: 1851-1862.

2. Soomro, A. H., T. Masud, and K. Anwaar. 2002. Role of Lactic Acid Bacteria (LAB) in Food Preservation and Human Health - A Review. Pakistan Journal of Nutrition 1 (1): 20-24.

3. Parveen, S. and F. Hafiz. 2003. Fermented cereal from indigenous raw materials. Pakistan Journal of Nutrition 2 (5): 289-291.

4. Speck, M. L. 1975. Contribution of microorganisms to food and nutrition Nutr. News 38: 13 .

5. Ouwehand, A. C. 1998. Antimicrobial components from lactic. Microbiology Reviews 12: 221-238.

6. Vandenberg, P. A. 1993. Lactic acid bacteria, their metabolic products and interference with microbial growth. FEMS Microbiology Reviews 12 221-238.

7. Food and Agriculture Organization (FAO) spotlight magazine. 1998 Small scale fermentation. Agriculture 21: 1-2.

8. Kobawila S. C., et. al. 2005. Reduction of the cyanide content during fermentation of cassava roots and leaves to produce bikedi and ntoba mbodi, two food products from Congo. Journal of Biotechnology 4 (7) 689-696,

9. Mishra, C. and J. Lambert. 1996. Production of antimicrobial substances by probiotics. Asia Pacific J. Clin. Nutr. 5: 20-24.

10. Nes, I. F., et al. 1996. Biosynthesis of bacteriocin in lactic acid bacteria .Antonie van Leeuwenhoek Int. J. Gen. Mol. Microbiol. 70: 113-128.

11. Marteau. P. and J. C. Rambaud. 1996. Therapeutic applications of probiotics in humans, p. 47-56.. In Leeds, A.R. and I. R. Rowland. (Eds.), Gut flora and health- Past, present, and future. The Royal Society of Medicine Press Ltd., London.

12. Ashurst, P. R. 1999. Food Flavorings. Springer-Verlag, Berlin.

13. Gill, H. S. and F. Guarner. 2004. Probiotics and human health: a clinical perspective. Post Grad. Med. J. 80: 516-26.

14. Gilliland, S. E. and M. L. Speck. 1977. Deconjugation of bile acids by intestinal lactobacilli. Appl Environ Microbiol. 33: 5-18.

15. Rettger, L. F., W. N. Levy, and L. Weinstein. 1935. Lactobacillus acidophilus and its therapeutic application. Yale University press.

16. Liao, C. C., A. E. Yuosef, E. R. Chism, and E. R. Richter. 1994 Inhibition of Staphylococcus aureus in buffer, culture media, and foods by lacidin A, a bacteriocin produced by Lactobacillus acidophilus. OSU 133. J. Food Safety 14: 87-101.
17. Helander, I. M., A. von Wright, and T. M. Mattila-Sandholm, 1997. Potential of lactic acid bacteria and novel antimicrobials against Gramnegative bacteria. Trends in Food Science and Technology 8: 146-150.

18. Mack, D. R., S. Michail, and S. Wet. 1999. Probiotics inhibit enteropathogenic $E$. coli adherence in vitro by inducing intestinal mucin gene expression. Am. J. Physiol. 276: G941-G950.

19. Mallett, A. K., C. A. Bearne, and I. R. Rowland. 1989. The influence of incubation $\mathrm{pH}$ on the activity of rat and human gut flora enzymes. J. Appl. Bacteriol. 66: 433-437.

20. Cherpes, T. L., L. A. Meyn, M. A. Krohn, and S. L. Hillier. 2003. Risk factors for infection with herpes simplex virus type 2: role of smoking, douching, uncircumcised males, and vaginal flora. Sex Transm. Dis. 30: 405410 .

21. Watts, D. H., et al. 2005. Effects of bacterial vaginosis and other genital infections on the natural history of human papillomavirus infection in HIV-1infected and high-risk HIV-1-uninfected women. J. Infect. Dis. 191: 11291139

22. Gorbach, S. L. 2000. Probiotics and gastrointestinal health. Am. J. Gastroenterol 95: S2-S4.

23. Fernandes, C. F., K. M. Shahani, and M. A. Amer. 1987. Therapeutic role of dietary lactobacilli and lactobacillic fermented dairy products. FEMS Microbiol. Rev. 46: 343-356.

24. Young, G. 1996. Prevention of colon cancer: role of short chain fatty acids produced by intestinal flora. Asia Pacific J. Clin. Nutr. 5: 44-47.

25. Rolfe, R. D. 2000. The role of probiotic cultures in the control of gastrointestinal health. J. Nutr. 130: 396S-402S

26. Rombeau, J. L., S. A. Kripke, and R. G. Settle. 1990. Short-chain fatty acids. Production, absorption, metabolism and intestinal affects, p. 317-337. In Kritchesvsky, D. (Eds.), Dietary Fiber: Chemistry, Physiology, and Health Effects. Plenum Press, New York and London.

27. Leavitt, J., J. C. Barrett, B. D. Crawford, and P. O. Tso. 1978. Butyric acid suppression on the in vitro neoplastic state of Syrian hamster cells. Nature 271 (5642): 262-5.

28. Leopold, C. S. and D. Eileler. 2000. Basic coating polymer for the colonspecific drug delivery in inflammatory bowel disease. Drug Dev. Ind. Pharm. 26: $1239-1246$.

29. Kaferstein, F., and M. Abdussalam. 1999. Food Safety in the 21st Century. Bull. WHO 77 (4): 347-351.

30. Geis, A., J. Singh, and M. Teuber. 1983. Potential of lacric streptococci to produce bacteriocin. Appl. Environ. Microbiol. 45: 205-211.

31. Barefoot, S. F., and T. R. Klaenhammer. 1983. Detection and activity of lactacin B, a bacteriocin produced by Lactobacillus acidophilus. Appl. Environ. Microbiol. 45: 1808-1815.

32. Toba, T., S. K. Samant, and T. Itoh. 1991: Assay system for detecting bacteriocin in microdilution wells. Lett. Appl. Microbiol. 13: 102-104.

33. Beukes, E. M., B. H. Bester, and J. F. Mostert. 2001. The microbiology of South African traditional fermented milks. International Journal Food Microbiology 63: 189-197. 